\title{
Analisis faktor-faktor yang mempengaruhi pembiayaan murabahah dan pengaruhnya terhadap return on asset (ROA)
}

\author{
Studi pada Bank Pembiayaan Rakyat Syariah (BPRS) di Indonesia \\ periode 2012-2015
}

\author{
Firmansyah Romadhona*, Sri Lestari, \& Sulistyandari
}

Fakultas Ekonomi dan Bisnis, Universitas Jenderal Soedirman, Purwokerto, Indonesia

*Email of corresponding author: firman.gendon@gmail.com

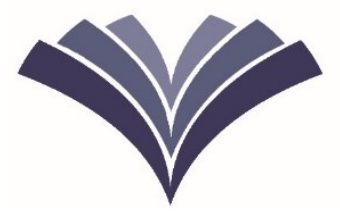

Performance

Vol. 24 No. 1, 2017 pp. 25-31

Published by Faculty of Economics and Business Jenderal Soedirman University on 2 January 2017

\section{DOI:}

10.20884/1.performance. 2017.24.1.314

ISSN:

1829-6467 (Print)

2615-8094 (Online)

How to cite this article: Romadhona, F., Lestari, S. \& Sulistyandari. (2017). Analisis faktor-faktor yang mempengaruhi pembiayaan murabahah dan pengaruhnya terhadap return on asset (ROA): Studi pada Bank Pembiayaan Rakyat Syariah (BPRS) di Indonesia periode 20122015. Performance, 24(1), 25-31.

https://doi.org/10.20884 /1.performance.2017.24.1 .314 .

This article is available at: http://jos.unsoed.ac.id/in dex.php/performance/ar ticle/view/314

or scan this with your mobile device

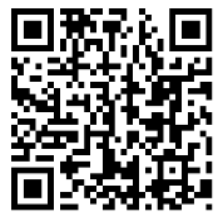

Received 24 November 2016 Revised 8 December 2016 Accepted 22 December 2016

\begin{abstract}
Abstrak
Tujuan: Tujuan dari penelitian ini adalah untuk menganalisis pengaruh pembiayaan bermasalah, tabungan wadiah, rasio pembiayaan terhadap cadangan, dan beban usaha pendapatan operasional terhadap pembiayaan murabahah dan pengaruh terhadap pengembalian aktiva.

Metodologi: Penelitian ini menggunakan analisis data regresi sebagai model untuk menguji hipotesis. Populasi dalam penelitian ini adalah Perbankan Syariah Nasional (BPRS) di Indonesia selama tahun 2012-2015 yang terdiri dari 168 bank. Sedangkan, sampel penelitian ini diambil dengan metode purposive sampling, yaitu 25 bank.

Hasil: Hasil penelitian menunjukkan bahwa: (1) pembiayaan bermasalah tidak berpengaruh terhadap pembiayaan murabahah, (2) tabungan wadiah berpengaruh positif terhadap pembiayaan murabahah, (3) rasio pembiayaan terhadap simpanan tidak berpengaruh terhadap pembiayaan murabahah, (4) beban usaha pendapatan operasional berpengaruh positif terhadap pembiayaan murabahah, dan (5) pembiayaan murabahah berpengaruh positif terhadap return on asset.

Implikasi: Implikasi berdasarkan hasil penelitian ini adalah manajemen perlu meningkatkan tabungan wadiah dan perlu menurunkan beban usaha pendapatan operasional karena dapat meningkatkan pembiayaan murabahah. Manajemen juga perlu meningkatkan pembiayaan murabahah, karena dalam penelitian ini terbukti dapat meningkatkan return on asset.

Kata kunci: pembiayaan bermasalah, tabungan wadiah, rasio pembayaran terhadap deposito, beban usaha operasi, pembiayaan murabahah, tingkat pengembalian aktiva.
\end{abstract}

\section{Abstract}

Purpose: The purpose of this research is to analyze the influence of non performing financing, wadiah savings, financing to deposit ratio, and operating income expense toward murabahah financing and the influence to return on asset.

Methodology: This research used panel data regression analysis as model to test the hypothesis. The population in this research was Sharia Rural Banking (BPRS) on Indonesia during 2012-2015 consisting of 168 banks. While, the sample of this research was taken by purposive sampling method which was 25 banks.

Findings: The result of this research shows that: (1) non performing financing has no effect toward murabahah financing; (2) wadiah savings has positive effect toward murabahah financing; 3) financing to deposit ratio has no effect toward murabahah financing; (4) operating income expense has negative effect toward murabahah financing; and (5) murabahah financing has positive effect toward return on asset.

Implications: Implication based on result of this research is the management needs to increase wadiah savings and decrease operating income expense because it can increase the murabahah financing. The management also needs to increase murabahah financing, because in this research it is proven that it can increase the return on asset.

Keywords: non performing financing, wadiah savings, financing to deposit ratio, operating income expense, murabahah financing, return on asset.

\section{PENDAhUluan}

Bank syariah adalah lembaga keuangan yang usaha pokoknya memberikan pembiayaan dan jasa-jasa lainnya dalam lalu lintas pembayaran serta peredaran uang yang pengoperasiannya disesuaikan dengan prinsip-prinsip syariat Islam (Sudarsono, 2012: 29). Menurut Undang-Undang No. 21 Tahun 2008, bank syariah adalah bank yang menjalankan kegiatan usahanya berdasarkan prinsip syariah dan menurut jenisnya terdiri atas Bank Umum Syariah dan Bank Pembiayaan Rakyat Syariah. Bank Pembiayaan 
Rakyat Syariah (BPRS) adalah perbankan yang unik, di mana bank ini beroperasi dalam skala kecil, diperuntukkan melayani usaha kecil dan mikro, dan BPRS beroperasi pada wilayah kabupaten ataupun kotamadya dengan jangkauan yang terbatas sebagaimana permodalannya yang relatif kecil. Namun, pada satu sisi BPRS adalah perbankan yang beroperasi terbatas, dengan permodalan mulai dari Rp 500 juta, yang tentunya pula dengan jumlah karyawan yang kecil, namun tidak dapat dipungkiri bahwa BPRS adalah sebuah bank atau suatu lembaga kepercayaan, yang harus dikelola sesuai prinsip-prinsip good corporate governace (GCG) (Siregar, 2008: 27).

Musyarakah adalah akad kerja sama antara dua pihak atau lebih untuk melakukan usaha tertentu. Masingmasing pihak memberikan dana atau amal dengan kesepakatan bahwa keuntungan atau risiko akan ditanggung bersama sesuai dengan kesepakatan. Sedangkan, mudharabah adalah akad kerja sama antara dua pihak, di mana pihak pertama menyediakan seluruh modal dan pihak lain menjadi pengelola. Keuntungan dibagi menurut kesepakatan yang dituangkan dalam kontrak. Apabila rugi, maka akan ditanggung pemilik modal selama kerugian itu bukan akibat dari kelalaian si pengelola. Apabila kerugian diakibatkan kelalaian pengelola, maka si pengelola yang bertanggung jawab (Kasmir, 2008). Murabahah merupakan pembiayaan yang memposisikan nasabah sebagai pembeli dan bank sebagai penjual, dan operasional murabahah ini murni menggunakan rukun dan syarat jual beli, di mana terdapat beberapa hal yang harus ada dalam transaksi jual beli tersebut. Harus ada penjual, pembeli, objek yang diperjual belikan, ada ijab dan qabul, serta ada akad yang menyertai perjanjian jual beli ini (Kasmir, 2008).

Menurut data dari Statistik Perbankan Syariah (2014) yang di publikasikan oleh OJK (Otoritas Jasa Keuangan) tentang komposisi pembiayaan BPRS di Indonesia, dari tahun 2008 sampai 2014, total pembiayaan yang berbasis piutang (murabahah) jauh lebih banyak dari pembiayaan yang berbasis bagi hasil (musyarakah dan mudharabah). Pada Desember 2014, tercatat pembiayaan berbasis piutang mencapai Rp 3.965 .545 juta, sedangkan pembiayaan berbasis bagi hasil sebesar Rp 690.125 juta. Untuk meningkatkan volume pembiayaan murabahah yang di salurkan BPRS, perlu diketahui faktor-faktor apa saja yang mempengaruhi pembiayaan berbasis bagi hasil. Menurut penelitian yang dilakukan oleh Wardiantika dan Kusumaningtias (2014), Ali (2016), Andraeny (2011), dan Adzimatinur et al. (2016), variabel yang memepengaruhi pembiayaan murabahah adalah DPK, non performing financing (NPF), tabungan wadiah, financing to deposit ratio (FDR), CAR, ROA, inflasi, dan tingkat bunga. Dalam penelitian ini, faktor-faktor yang mempengaruhi pembiayaan murabahah yaitu non performing financing (NPF), tabungan wadiah, financing to deposit ratio (FDR), dan BOPO. Hal ini dikarenakan variabel tersebut ditolak terhadap pembiayaan murabahah pada penelitian Jamilah dan Wahidahwati (2013) dan Dewi dan Wirajaya (2013). Dengan meningkatnya pembiayaan murabahah yang disalurkan, diharapkan akan meningkatkan profitabilitas. Profitabilitas umumnya diukur oleh return on asset (ROA) yang memperlihatkan kemampuan perusahaan dalam menghasilkan laba dari aktiva yang digunakan. ROA sangat penting bagi bank karena digunakan untuk mengukur efektivitas perusahaan di dalam menghasilkan keuntungan dengan memanfaatkan aktiva yang dimilikinya (Adyani, 2011).

\section{TINJAUAN PUSTAKA DAN HIPOTESIS}

\section{Bank syariah}

Pada umumnya, yang dimaksud dengan bank syariah adalah lembaga keuangan yang usaha pokoknya memberikan pembiayaan dan jasa-jasa lain dalam lalu lintas pembayaran serta peredaran uang yang beroperasi disesuaikan dengan prinsip-prinsip syariah (Sudarsono, 2012: 27).

\section{Bank Perkreditan Rakyat Syariah (BPRS)}

Pembiayaan Rakyat Syariah (BPRS) adalah BPR yang sistem operasionalnya mengikuti prinsip-prinsip muamalah Islam. Sedangkan, usaha bank perkreditan rakyat meliputi penyediaan pembiayaan bagi nasabah berdasarkan prinsip bagi hasil sesuai dengan ketentuan yang ditetapkan dalam Peraturan Pemerintah (PP) Nomor 72 tahun 1992.

\section{Return on asset (ROA)}

Return on asset (ROA) atau yang sering disebut sebagai rentabilitas ekonomis merupakan ukuran kemampuan peruasahaan dalam menghasilkan laba dengan semua aktiva yang dimiliki oleh perusahaan (Sutrisno, 2009: 222). 


\section{Pembiayaan murabahah}

Kata al-murabahah diambil dari bahasa Arab dari kata ar-ribhu yang berarti kelebihan dan tambahan (keuntungan). Sedangkan, dalam definisi para ulama terdahulu adalah jual beli dengan modal ditambah keuntungan yang diketahui. Hakekatnya adalah menjual barang dengan harga (modal) nya yang diketahui kedua belah transaktor (penjual dan pembeli) dengan keuntungan yang diketahui keduanya (Kasmir, 2008).

\section{Non performing financing (NPF)}

Merupakan hilangnya kesempatan memperoleh kesempatan pendapatan (income) dari kredit yang diberikan. Sehingga, mengurangi laba dan mengurangi kemampuan untuk memberikan kredit. Salah satu risiko yang dihadapi bank dalam menyalurkan kredit adalah tidak terbayarnya kredit yang telah diberikan atau biasa disebut risiko kredit. NPF mencerminkan kemampuan bank dalam mengelola risiko kredit yang timbul dari berbagai kredit masuk yang tergolong kredit bermasalah. Banyaknya kredit bermasalah membuat bank tidak berani meningkatkan penyaluran kreditnya, apalagi bila dana pihak ketiga tidak dapat dicapai secara optimal, maka dapat mengganggu likuiditas suatu bank. Oleh karena itu, semakin besar kredit bermasalah, semakin kecil kredit yang dapat disalurkan bank pada masyarakat mengingat risiko kredit yang timbul (Dendawijaya, 2009).

\section{Tabungan wadiah}

Tabungan wadiah merupakan salah satu produk bank syariah yang menggunakan akad wadiah. Karena menggunakan akad wadiah, untuk ketentuan rukun, syarat, dan bonusnya sama dengan giro wadiah. Akad wadiah dalam tradisi fikih Islam dikenal dengan simpanan. Wadiah dapat juga diartikan titipan murni dari satu pihak kepada pihak lain, baik sebagai individu maupun sebagai suatu badan hukum. Titipan yang dimaksud harus dijaga dan dikembalikan kapan saja sipenitip menghendaki (Kasmir, 2008).

\section{Financing to deposit ratio (FDR)}

Financing to deposit ratio (FDR) dalam bank syariah yang analog dengan loan to deposit ratio (LDR) pada bank konvensional merupakan rasio yang menyatakan seberapa jauh kemampuan bank dalam membayar kembali penarikan dana yang dilakukan deposan dengan mengandalkan pembiayaan yang diberikan sebagai sumber likuiditasnya (Dendawijaya, 2009).

\section{Biaya operasional pendapatan operasional (BOPO)}

Rasio beban operasional pendapatan operasional (BOPO) merupakan biaya operasional pendapatan operasional atau rasio yang digunakan untuk mengukur tingkat efisiensi dan kemampuan bank dalam melakukan kegiatan operasinya (Rivai, 2013). Menurut Hasibuan (2011), biaya operasional terhadap pendapatan operasional (BOPO) merupakan perbandingan atau rasio biaya operasional dalam 12 bulan terakhir terhadap pendapatan operasional dalam periode yang sama.

\section{Hipotesis dan model penelitian}

$\mathrm{H}_{1}$ : Non performing financing (NPF) berpengaruh negatif terhadap pembiayaan murabahah.

$\mathrm{H}_{2}$ : Tabungan wadiah berpengaruh positif terhadap pembiayaan murabahah.

$\mathrm{H}_{3}$ : Financing to deposit ratio (FDR) berpengaruh positif terhadap pembiayaan murabahah.

$\mathrm{H}_{4}$ : Biaya operasional pendapatan operasional (BOPO) berpengaruh negatif terhadap pembiayaan murabahah.

$\mathrm{H}_{5}$ : Pembiayaan murabahah berpengaruh positif terhadap return on asset (ROA).

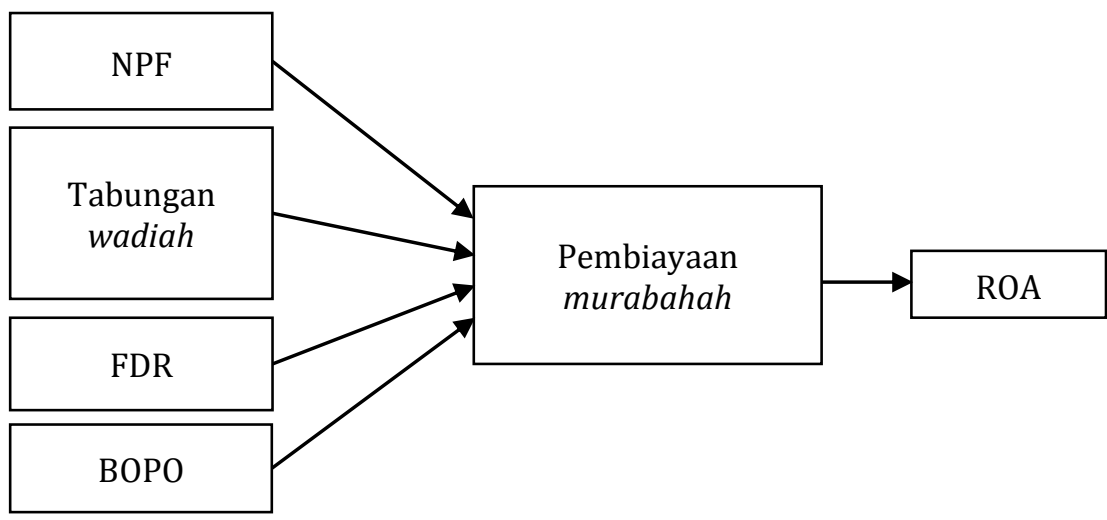

Gambar 1. Model hipotesis penelitian 


\section{METODE PENELITIAN}

\section{Statistik desktiptif variabel penelitian}

Analisis statistik deskriptif digunakan untuk mengetahui gambaran atau deskripsi data dari masing-masing variabel dalam penelitian ini, yaitu non performing financing, tabugan wadiah, financing to deposit ratio, biaya operasional pendapatan operasional, pembiayaan murabahah, dan return on asset. Hasil statistik desktiptif terhadap variabel penelitian disajikan dalam Tabel 1.

Tabel 1. Statistik deskriptif variabel BPRS tahun 2012-2015

\begin{tabular}{lcccc}
\hline Variabel & Minimum & Maksimum & Rata-rata & Standar deviasi \\
\hline Non performing financing (\%) & 1,12 & 30,42 & 8,97 & 6,07 \\
Tabungan wadiah & 3,13 & 8,01 & 5,98 & 0,97 \\
Financing to deposit ratio (\%) & 59,99 & 198,90 & 90,51 & 24,95 \\
Biaya operasional pendapatan operasional (\%) & 0,32 & 1,39 & 0,64 & 0,20 \\
Pembiayaan murabahah & 6,19 & 8,40 & 7,01 & 0,53 \\
Return on asset (\%) & $-10,96$ & 17,60 & 0,20 & 12,68 \\
\hline
\end{tabular}

\section{Uji asumsi klasik}

Uji asumsi klasik bertujuan untuk mengetahui apakah model regresi tersebut merupakan model regresi yang baik, dalam arti penyimpangannya minimum seperti pada asumsi OLS (Ordinary Least Square). Model yang digunakan dalam penelitian ini adalah model kuadra kecil (common effect).

\section{Uji heterokedastisitas}

Menurut Gujarati (2009: 500), gejala heterokedastisitas pada regresi data panel dapat dihiilangkan dengan pendekatan common effect dengan memilih cross section weight pada saat melakukan estimasi. Pada penelitian ini, model yang terpilih adalah common effect sehingga masalah heterokedastisitas dapat teratasi.

\section{Uji multikolinieritas}

Pengujian multikolinearitas dapat dilakukan dengan cara melihat adjusted $R$ square dan melihat tingkat signifikansi masing-masing variabel independen. Apabila nilai adjusted $R$ square cukup tinggi dan tidak ada variabel independen yang signifikan, diprediksi terdapat multikolinearitas dalam model. Namun, masalah multikolinearitas telah teratasi dengan panel data (Gujarati, 2009). Jadi, masalah multikolinearitas dalam penelitian ini dapat diabaikan karena model yang digunakan sudah di estimasi menggunakan model estimasi cross section weight.

\section{Uji autokorelasi}

Autokorelasi adalah hubungan antara residual satu observasi dengan residual observasi lainnya. Autokorelasi lebih mudah timbul pada data yang bersifat runtut waktu, karena berdasarkan sifatnya, data masa sekarang dipengaruhi oleh data pada masa-masa sebelumnya. Meskipun demikian, tetap dimungkinkan autokorelasi dijumpai pada data yang bersifat antar objek. Hasil pengujian autokorelasi dapat dilihat pada Tabel 2.

Tabel 2. Hasil uji autokorelasi pembiayaan murabahah sebagai variabel dependen

\begin{tabular}{ccccc}
\hline R square & Adj. R square & S.E of regression & Prob. $\left(F_{\text {statistic }}\right)$ & Durbin-Watson stat. \\
\hline 0.495483 & 0.474240 & 0.410651 & 0,000 & 1.629518 \\
\hline
\end{tabular}

Pada Tabel 2, diketahui nilai koefisien Durbin-Watson sebesar 1,629518. Nilai tersebut dibandingkan dengan nilai Durbin-Watson tabel untuk $\mathrm{n}=100 \mathrm{dan} \mathrm{k}=4$ dengan alpha $5 \%(0,05)$, maka diperoleh nilai $\mathrm{dL}=1,592 \mathrm{dan}$ $\mathrm{dU}=1,756$. Berdasarkan nilai $\mathrm{dU}$ dan $\mathrm{dL}$ tersebut, selanjutnya dapat dihitung nilai $4-\mathrm{dL}=2,408$ dan nilai $4-\mathrm{dU}=$ 2,224 .

Tabel 3. Hasil uji autokorelasi ROA sebagai variabel dependen

\begin{tabular}{|c|c|c|c|c|}
\hline R square & Adj. R square & S.E of regression & Prob. $\left(F_{\text {statistic }}\right)$ & Durbin-Watson stat. \\
\hline 0.236723 & 0.228934 & 11.50270 & 0,000 & 1.941543 \\
\hline
\end{tabular}

Pada Tabel 3, diketahui nilai koefisien Durbin-Watson sebesar 1,629518. Nilai tersebut dibandingkan dengan nilai Durbin-Watson tabel untuk $\mathrm{n}=100$ dan $\mathrm{k}=4$ dengan alpha 5\% $(0,05)$, maka diperoleh nilai $\mathrm{dL}=1,654 \mathrm{dan}$ 
$\mathrm{dU}=1,694$. Berdasarkan nilai $\mathrm{dU}$ dan $\mathrm{dL}$ tersebut, selanjutnya dapat dihitung nilai $4-\mathrm{dL}=2,346$ dan nilai $4-\mathrm{dU}=$ 2,306 .

\section{HASIL}

\section{Uji koefisiensi determinasi}

Berdasarkan hasil perhitungan pada Tabel 2, dapat diketahui nilai adjusted $R$ square sebesar 0,474 . Hal ini menunjukan bahwa perubahan variabel pembiayaan murabahah pada BPRS dijelaskan oleh variabel-variabel bebas, yaitu deposito NPF, tabungan wadiah, FDR, dan BOPO sebesar 47,4 persen. Sedangkan, sisanya sebesar 52,6 persen dijelaskan oleh variabel-variabel lain yang tidak diteliti, yaitu CAR, ROA, inflasi, dan tingkat bunga. Kemudian, berdasarkan hasil perhitungan pada Tabel 3, dapat diketahui nilai adjusted $R$ square sebesar 0,229. Hal ini menunjukan bahwa perubahan variabel ROA pada BPRS dijelaskan oleh variabel pembiayaan murabahah sebesar 22,9 persen. Sedangkan, sisanya sebesar 77,1 persen dijelaskan oleh variabel-variabel lain yang tidak diteliti, yaitu pembiayaan mudharabah, pembiayaan musyarakah, dan DPK.

\section{Uji simultan (uji F)}

Nilai Fhitung digunakan untuk ketepatan model. Uji F ini juga sering disebut sebagai uji simultan, untuk menguji apakah variabel bebas yang digunakan dalam model mampu menjelaskan perubahan nilai variabel tergantung atau tidak. Untuk menyimpulkan apakah model masuk dalam kategori cocok (fit) atau tidak, kita harus membandingkan nilai probabilitas $\mathrm{F}$ dengan $\alpha$ yaitu 0,05 . Kriteria pengujiannya adalah apabila nilai Sig. $\mathrm{F}<\alpha$ $(0,05)$, maka persamaan regresi yang digunakan baik (goodness of fit), apabila Sig. F $>\alpha(0,05)$, maka persamaan regresi yang digunakan tidak baik. Pada Tabel 2 dapat diketahui bahwa nilai probabilitas $\mathrm{F}$ pada penelitian ini sebesar 0,000 atau $<\alpha(0,05)$, maka model regresi pada penelitian ini dinyatakan baik dan secara simultan variabel NPF, tabungan wadiah, FDR, dan BOPO berpengaruh terhadap pembiayaan murabahah. Kemudian, pada Tabel 3 diketahui bahwa nilai probabilitas F pada penelitian ini sebesar 0,000 atau $<\alpha(0,05)$, maka model regresi pada penelitian ini dinyatakan baik dan variabel pembiayaan murabahah berpengaruh terhadap ROA.

\section{Uji statistik t}

Nilai thitung digunakan untuk menguji apakah variabel tersebut berpengaruh secara signifikan terhadap variabel tergantung atau tidak. Satu variabel akan memiliki pengaruh yang berarti jika probabilitas kurang dari $\alpha$. Apabila probabilitas $\mathrm{t}<\alpha(0,05)$, maka Ha akan diterima dan Ho ditolak.

Tabel 4. Ringkasan hasil uji statistik $\mathrm{t}$

\begin{tabular}{lccc}
\hline Variabel & Coefficient & $t_{\text {statistic }}$ & Prob. \\
\hline NPF $\left(\mathrm{X}_{1}\right)$ & 1,919707 & 1,919707 & 0,0579 \\
Tabungan wadiah $\left(\mathrm{X}_{2}\right)$ & 0,226565 & 6,665654 & 0,0000 \\
FDR $\left(\mathrm{X}_{3}\right)$ & 0,000253 & 0,202484 & 0,8400 \\
BOPO $\left(\mathrm{X}_{4}\right)$ & $-1,126962$ & $-5,370363$ & 0,0000 \\
Pembiayaan murabahah $\left(\mathrm{X}_{5}\right)$ & 6,208569 & 5,513051 & 0,0000 \\
\hline
\end{tabular}

\section{KESIMPULAN}

Non performing financing (NPF) tidak berpengaruh terhadap pembiayaan murabahah. Artinya bahwa semakin tinggi non performing financing (NPF) Bank Pembiayaan Rakyat Syariah (BPRS), tidak menyebabkan pembiayaan murabahah yang disalurkan berkurang. Hal ini diduga BPRS mendapatkan porsi pembiayaan bermasalah atau non performing financing (NPF) tersebut merupakan non performing financing (NPF) dari penyaluran pembiayaan untuk suatu produk akad murabahah tertentu, namun untuk produk yang lain tetap dilakukan penyaluran pembiayaan murabahah. Dari hal tersebut, meskipun non performing financing (NPF) naik, pembiayaan murabahah yang disalurkan juga mengalami kenaikan, tabungan wadiah berpengaruh positif terhadap pembiayaan murabahah. Artinya bahwa semakin tinggi tabungan wadiah yang diperoleh Bank Pembiayaan Rakyat Syariah (BPRS), akan meningkatkan pembiayaan murabahah yang disalurkan. Hal ini diduga pihak manajemen dapat menyalurkan pembiayaan murabahah lebih banyak karena mendapatkan modal gratis dari tabungan wadiah yang telah dihimpun.

Financing to deposit ratio (FDR) tidak berpengaruh terhadap pembiayaan murabahah. Artinya bahwa semakin tinggi financing to deposit ratio (FDR) yang dihimpun oleh Bank Pembiayaan Rakyat Syariah (BPRS) tidak meningkatkan pembiayaan murabahah yang disalurkan. Hal ini diduga pembiayaan murabahah yang disalurkan 
tidak bergantung pada besarnya financing to deposit ratio (FDR) saja, tetapi juga bergantung pada investai lain dan modal. Biaya operasional pendapatan operasional (BOPO) berpengaruh negatif terhadap pembiayaan murabahah. Artinya bahwa semakin tinggi BOPO dari Bank Pembiayaan Rakyat Syariah (BPRS), akan menurunkan volume pembiayaan murabahah yang disalurkan. Hal ini diduga BOPO yang tinggi merupakan indikasi bahwa kegiatan operasional yang dilakukan oleh BPRS tidak efektif, sehingga pembiayaan murabahah yang disalurkan menjadi kurang maksimal.Pembiayaan murabahah berpengaruh positif terhadap return on asset (ROA). Artinya bahwa semakin tinggi pembiayaan murabahah yang diperoleh Bank Pembiayaan Rakyat Syariah (BPRS), akan meningkatkan return on asset (ROA) yang diperoleh. Hal ini diduga pihak manajemen ingin meningkatkan ratio profitabilitas dengan cara menigkatkan pembiayaan murabahah yang disalurkan.

\section{IMPLIKASI}

\section{Implikasi praktis}

Bagi pihak Bank Pembiayaan Rakyat Syariah, hendaknya lebih meningkatkan volume pembiayaan murabahah yang disalurkan. Hal ini dikarenakan pembiayaan murabahah mampu meningkatkan profitabilitas. Pihak Bank Pembiayaan Rakyat Syariah juga hendaknya meningkatkan tabungan wadiah yang terbukti akan meningkatkan pembiayaan murabahah dan menurunkan nilai BOPO atau mengurangi biaya operasional agar lebih efektif, karena BOPO terbukti menurunkan pembiayaan murabahah yang disalurkan. Bagi pihak manajemen Bank Pembiayaan Rakyat Syariah, hendaknya tetap menjaga nilai non performing financing (NPF) dari penyaluran pembiayaan untuk suatu produk akad murabahah tertentu yang terdapat banyak kredit macet dan menaikkan nilai financing to deposit ratio (FDR), karena jika dianalisis, hal tersebut dapat menaikkan jumlah pembiayaan murabahah yang disalurkan.

\section{Implikasi teoritis}

Penelitian ini terbatas hanya empat variabel bebas, yaitu non performing financing, tabungan wadiah, financing to deposit ratio, dan biaya operasional pendapatan operasional. Sehingga, untuk penelitian selanjutnya, perlu adanya penambahan variabel lain yang diduga akan berpengaruh terhadap pembiayaan murabahah, seperti deposito mudharabah, dewan pengawas syariah, dan kewajiban penyediaan modal minimum. Penggunaan regresi data panel pada penelitian ini sangat tepat. Hal ini karena data yang digunakan adalah gabungan antara data cross section dan data time series, sehingga memudahkan peneliti dalam penghitungan estimasi regresi. Untuk penelitian selanjutnya, diharapkan untuk menggunakan regresi data panel jika datanya adalah perpaduan antara time series dengan cross section. Sampel yang didapat pada penelitian ini terbatas hanya 25 sampel dari 168 jumlah Bank Pembiayaan Rakyat Syariah yang ada di Indonesia, hal ini disebabkan masih banyak BPRS yang tidak mempublikasikan laporan keuangannya secara konsisten. Untuk penelitian selanjutnya, diharapkan menggunakan subjek jenis perbankan syariah lainnya agar dapat memperoleh hasil yang lebih akurat.

\section{DAFTAR PUSTAKA}

Adyani, R.L. (2011). Analisis faktor-faktor yang mempengaruhi profitabilitas (ROA). Skripsi. Universitas Diponegoro. (Tidak dipubilkasikan).

Adzimatinur, F., Hartoyo, S., dan Wilasih, R. (2016). Faktor-faktor yang mempengaruhi besaran pembiayaan perbankan syariah di Indonesia. Al-Muzara'ah, 3(2).

Ali, M.H. (2016). Determinan yang mempengaruhi pembiayaan murabahah pada perbankan syariah di Indonesia. Jurnal Bisnis dan Manajemen, 6(1), 31-44.

Andraeny, D. (2011). Analisis pengaruh dana pihak ketiga, tingkat bagi hasil, dan non performing financing terhadap volume pembiayaan berbasis bagi hasil pada perbankan syariah di Indonesia. Simposium Nasional Akuntansi, 14.

Dendawijaya, L. (2009). Manajemen perbankan. Jakarta: Ghalia Indonesia.

Dewi, A.S.M. dan Wirajaya, A. (2013). Pengaruh struktur modal, profitabilitas, dan ukuran perusahaan pada nilai perusahaan. E-Jurnal Akuntansi, 4(2), 358-372.

Gujarati, D. (2009). Ekonometri dasar, terjemahan: Sumarno Zain. Jakarta: Erlangga.

Jamilah dan Wahidahwati. (2013). Faktor yang mempengaruhi pembiayaan mudharabah pada bank umum syariah di Indonesia. Jurnal Ilmu dan Riset Akuntansi, 2(1).

Hasibuan, M. (2011). Manajemen sumber daya manusia. Jakarta: Bumi Aksara.

Kasmir. (2008). Dasar-dasar perbankan. Jakarta: Raja Grafindo. 
Rivai, V. (2013). Credit management handbook manajemen perkreditan: Cara cara mudah menganalisis kredit. Jakarta: Rajagrafindo Persada.

Siregar, S. (2008). Performance appraisal pada BPRS. Jurnal Manajemen Bisnis.

Sudarsono, H. (2012). Bank dan lembaga-lembaga keuangan syariah deskripsi dan ilustrasi. Yogyakarta: Ekonisia.

Sutrisno. (2009). Manajemen keuangan teori, konsep, dan aplikasi. Yogyakarta: Ekonisia.

Wardiantika, L. dan Kusumaningtias, R. (2014). Pengaruh DPK, CAR, NPF, dan SWBI terhadap pembiayaan murabahah pada bank. 